\title{
Correlational Study of Culturally-Based Instructional Strategy and Cognitive Competencies on Problem Solving, Speaking and Listening: An Evidence in Oyo State Nigeria.
}

\author{
Oluyemisi Majebi1, Esther Oduolowu ${ }^{2}$ \\ ${ }^{1}$ Early Childhood and Educational Foundations, Nigeria \\ ${ }^{2}$ Sokoto State University, Nigeria
}

\begin{abstract}
The study examined the impact of culturally based Instructional strategy (indigenous songs, rhymes, games, stories, language of the immediate environment, and instructional materials) on pre-primary school children's cognitive competence with special attention on problem-solving, speaking, and listening skills. Socio-cultural theory provided the framework, while pretest-posttest control group quasi-experimental design was adopted. 74 children ( 44 males and 30 females) with a mean age of 5.61 from four pre-primary schools (two public and private schools) were purposively selected from two local government areas and randomized into CIBS and conventional groups, respectively. Children's Cognitive Competency Rating Scale ( $r=0.89$ ) and CBIS Instructional Guide were the instruments used to collect data for the study. Paired sample t-test and Analysis of covariance (ANCOVA) were used to analyze the data. There was a significant main effect of treatment on children's cognitive competence $\left(\mathrm{F}(1,65)=10.31\right.$; partial $\left.\tilde{\eta}^{2}=0.14\right)$. CIBS was found to be potent in enhancing pre-primary school children's cognitive competence, especially in the area of problemsolving, speaking, and listening skills. Teaching and learning activities at the pre-primary school level should employ a culturally-based instructional strategy.
\end{abstract}

Keywords: Culturally-based instructional strategy, cognitive competence, problem-solving, speaking and listening skills.

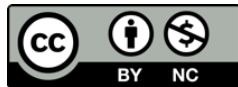

This is an open access article under the CC-BY-NC license.

\section{INTRODUCTION}

So much preference for foreign educational materials and philosophy in Nigeria is exhibited in every education segment, ranging from curriculum to instructional strategy. The classrooms, especially the preschool classes, depend largely on instructional strategies that are Euro-Western orientated. Most of the strategies adopted during the teaching and learning activities at this level are less culturally relevant. These have been associated with the non-relevance of such educational attainment to the immediate environment because culture plays a prominent role in the teaching and learning process. Research evidence from descriptive and experimental studies, both local and international, have linked meaningful learning with culture. Berk and Winsler (2002) and Darling-Hammond, Austin, Lit, Nasir, Moll, and Ladson Billings (2008) claim that human beings are cultural animals; they are products of their cultural upbringing and cultural environments. Gay (2000), Rogoff (2003), Obanya (2007), Ritterhouse (2007), Fries-Gaither (2009), Chartock (2010), and Gwanfogbe (2011) assert that the teaching and learning process has its root in culture and culture is central to learning.

This implies that the culture of the people cannot be ignored in the teaching and learning process specifically for effectiveness and meaningfulness. It has a strong influence on educational practices, especially how people teach and how they learn. Culture influences how people process learning, solve

Corresponding author yemfoks70@yahoo.com; omorinola2000@yahoo.com 
problems and teach (Saifer, Edwards, Elli, Lena Ko, Stuczynski, Dorfman, and Kirkham 2005). It produces the needed content for the educational curriculum and plays an active role in facilitating effective learning. It also has a strong link with the understanding of people's learning styles. Hills (2012) asserts that understanding the culture of a society is the key to understanding the way people learn. Thus, the instructional strategy to be adopted in the course of teaching ought to have a base in the culture of the immediate society since culture, education, and learning are interrelated (Azubuike 2013). The early years pose a good chance of introducing a strategy that is culturally based to children.

\section{LITERATURE REVIEW}

The early years, if properly handled, have been confirmed to lay a solid foundation for the holistic development of the child, cognitive competence inclusive. Cognitive competence is usually inferred from children's academic excellence, motor activities, communication, or social behaviors during their learning, play, and daily activities. As expressed by UNESCO (2003), cognitive competence is learning to know, which implies learning how to learn by developing one's concentration, memory skills, and ability to think. Scrimsher and Tudge (2003) explain cognitive competence from social and cultural points of view. It is social because children learn through interactions with others and require assistance from others to learn what they need to know and culture because what children need to know is determined by the culture of their environment. Michelon (2006) describes it as a competence that has more to do with the mechanisms of how we learn, remember, solve problems, and pay attention. It can be said summarily that cognitive competence is demonstrated in performing tasks that involve reasoning, remembering, adapting, transferring, and applying wisdom to adequately proffer a solution to the problem at hand. All these components have their root in the culture of people.

Vygotsky's assertion says that tools of intellectual adaptation are available in each culture to help children develop adaptive thinking and problem-solving strategies (Wang, Ceci, Williams, and Kopko, 2004). Thus, points to the fact that there is a strong connection between the cognitive competence of the child and his/her culture. This means that the development of cognitive competence might not be culturally neutral. The former can be strengthened during the early years when teaching and learning activities employ culturally-based instructional strategies. This is why Butler (2011) affirms that culture plays a role in conveying and receiving information and shaping an individual's thinking process. Wang et al. (2004) assert that people in different cultures have been shown to possess different cognitive competence unique to their living environment. And most times, this type of competency has been found to be beneficial to the environment. Neglecting culture and culturally based instruction strategy in the process of acquiring this competence might affect children's acquisition of necessary skills that can make them relevant in their immediate environment.

Cognitive competence involves so many skills; this study focuses on problem-solving, speaking, and listening skills. These were given consideration because they are frequently used in day-to-day activities and can easily be translated into developing other skills needed to make a meaningful contribution to one's immediate environment. Problems are part of everyday life and can be handled differently depending on what the situation presents and the skill that the person involved possesses. Problemsolving skills can be explained as analyzing a situation and forming and applying a workable solution to arrive at an expected solution. It could also mean staying on a difficult task and applying different tactics or strategies until an expected result is achieved.

Mayer and Wittrock (2009) describe problem-solving as a cognitive process directed at transforming a problem from the given state to the goal state when the problem solver is not immediately aware of a 
solution method. It thus means, developing a problem-solving skill goes beyond supplying an answer to an exercise in the classroom; it includes searching for or exploring every possible means to finding solutions to a problem. Previous knowledge gained can also be transferred to solve a problem at hand. Some of the subsets of problem-solving might be employed to achieve these. According to Mayer and Wittrock (2009), these subsets of problem-solving skills include abilities to reason, make decisions, think critically, and creatively. All these are required to be able to provide a solution to a problem.

Meanwhile, Oduolowu (1998) had earlier pointed out that the conscious development of the cognitive skill, especially the problem-solving skill, is still alien to the primary school system in Nigeria. This author made this assertion because most of the children's activities are paper-pencil based. Activities that can consciously prompt problem-solving skills are not organized for children during the teaching and learning activities. The problem still persists, and the pre-primary school level is not left out of this situation. Salami (2014) established that majority of children's classroom activities are still paper-pencil based. This might be one of the possible factors responsible for poor performance in Mathematics in Nigeria. Children's poor performance in problem-solving has been linked with poor performance in mathematics (Salami, 2014). An instructional strategy that is culturally based possesses diverse culturally relevant activities that can be used to engage children in meaningful problem-solving activities.

Closely related to problem-solving skills are speaking and listening skills. Children that possess good listening and speaking skills may likely stand a higher chance of exhibiting problem-solving skills. They might be able to ask questions related to the task at hand and listen to instructions from others. They might be able to discuss the problem encountered and the process of solving it. Speaking and Listening skills are part of the indices of cognitive competence. They are two sides of a coin in communication skills, they are interrelated; speaking skill is the ability to make an expression known through the use of verbal symbols or sign while listening is the ability to receive and decode the expression.

Speaking is an expressive language skill in which the speaker uses verbal symbols to communicate (Oduolowu and Amosun, 2010). It was also described as the process of building and sharing the message through the use of verbal and non-verbal symbols in a variety of contexts (Šolcová, 2011). Speaking can then be described as a verbal or signal expression of one's thinking, emotion, and relationship with others. It plays a significant role in the dissemination of information and ideas. Listening is as important as what is being said (speaking). Hearing is often mistaken as listening; the two differ. Thus, hearing precedes listening. Listening skill involves the ability to hear what people are saying accurately, respond promptly and relay it precisely if necessary. According to Okoro (2006), listening involves the ability to encode and decode a heard message. Jalongo (2008) describes it as the process of taking in information through the sense of hearing and making meaning from what is being heard. Oduolowu and Amosun (2010) conceive listening as the ability to select sound information that one wants to hear in order to perceive it in a clear and organized fashion. Listening skill is an important aspect of the cognitive development of children. Brown (2012) observes that developing good listening skills will help children to cope with the academic demands of school. Children who are active listeners can incorporate the things they hear faster in their framework of knowledge than their more passive counterparts. They can also exhibit better concentration and memory when they develop good listening skills (Tramel, 2011). The culturally-based instructional strategy has different activities that can enhance these skills in children. Some of which include storytelling, singing, and recitation of rhymes which were adopted in this study. 
Despite the relevance of speaking and listening skills to children's learning, researchers have established that little or no attention is devoted to these skills in the classroom. Oduolowu and Amosun (2010) observe that these two skills have suffered neglect and are taught least often in the classroom. Also, most of the practices in Nigeria's pre-primary and primary classrooms are not conscious of the influence of culture on the development of children's cognitive competence, especially in problem-solving, speaking, and listening skills. These aspects of a child's development were not handled with negligence in the cultural practice of the people. Children were engaged in activities such as storytelling, indigenous games, rhymes, tongue-twisting, proverbs, among others, to enhance their intellectual development.

However, reports from different studies have revealed that these multidimensional practices are fading out gradually, and the results are obvious in the products. For instance, Fakeye (2010) reports that teaching and learning activities are being carried out at the early childhood level using English as a medium of instruction. Roy-Omoni (2010) notes that children in their formative years are denied the teaching and learning through their mother tongue, contrary to the recommendation from the national policy on education in Nigeria. The local language has become outmoded and displaced in the teaching and learning process (Obioha 2010). Salami and Oyaremi 2012; Akinwale (2013) note that African children are exposed to games, toys, songs, nursery rhymes that have no direct relationship with what the growing children are likely to encounter in their immediate environments. Also, most of the teaching materials are imported. Ekukinam (2012). The need to bring all these valued ways of effective teaching and learning activities back into the educational system calls for an instructional strategy that acknowledges the relevance of culture in developing cognitive competencies.

Giving culture its due recognition in education, especially in classroom teaching and learning activities, is the root of culturally-based instructional strategy (CBIS). Culturally-based instructional strategy, in this context, is originally known as culturally responsive classroom practices. It was created by Gloria LadsonBillings to describe a pedagogy that empowers children intellectually, socially, emotionally, and politically by using cultural referents to impart knowledge, skills, attitudes, and values. It utilises the pupils' backgrounds, knowledge, and experiences to inform the teacher's lessons and methodology (Coffey 2008). CBIS is described as the instructional strategy that is grounded in an understanding of the role of culture in the teaching and learning process (Underwood, 2009). Alaska Native Knowledge Network (1998) views the strategy as a way of shifting the focus in the curriculum from teaching/learning about cultural values as another subject to teaching/learning through the local culture as a foundation for all educational activities.

A culturally-based instructional strategy is a form of strategy that employs the indigenous process and activity to facilitate meaningful and effective teaching and learning in the classroom. It gives adequate attention to the relevance of indigenous songs, stories, games, rhymes, the language of the immediate environment, and materials found in the immediate environment on achieving meaningful teaching and learning. And also help to equip the children from the society to improve the society. It engages practices that are culturally, developmentally, contextually, and child's friendly in the classroom to achieve holistic development of the child.

CBIS is a form of teaching based on the assumption that children's academic achievement can be improved when knowledge and skills are presented in ways that are consistent with their cultural frame of reference (Gay, 2000). Gay (2000) and King (2012) note that CBIS recognizes that pupils learn in many different ways. These practices maintain that varied instructional techniques are a critical part of teaching responsively. Dawes and Biersteker (2011) see a culturally-based instructional strategy that encourages 
children's total engagement in learning through participation and interaction in activities. The literature revealed that the strategy is dynamic and is not characterised by the classroom's routines and rituals. Each theme or topic taught is backed up with relevant indigenous stories, rhyme, and songs. CulturallyBased Instructional Strategy (CBIS) emphasises a learner-center strategy where children are exposed to opportunities and activities to express themselves verbally or non-verbally through indigenous stories, games, rhymes, and songs. These indigenous games and songs have their own effects on children's holistic development. Durojaiye (1977) had earlier submitted that when the traditional games are used in nursery schools, it is a way of giving children a chance to learn and pass on to the next generation what has been taken away from their background traditional.

A substantial number of findings from experimental studies from Western countries on culturally-based instructional strategy has revealed that any culturally appropriate strategy has a positive impact on students' learning outcomes. The strategy is effective in increasing students' achievement in any subject area (Moyo 2009; Underwood 2009; Peterek, 2009; Thompson, 2010; Hills, 2012; Mayfield, 2012; Thoms 2014; Paulk, Martinez and Lambeth 2014). It ensures academic success and could also enhance the acquisition of cognitive competence because this strategy, according to Erickson (2010), is rooted in the belief that everything in education relates to culture, its acquisition, transmission, and intervention. All learning is mediated by culture. This means that if culture is neglected in education, it might not yield the expected result. If it is a good one, education must be rooted in and guided by the culture of the society concerned. The study is hinged on Socio-cultural Theory. Lev Vgyotsky propounded this theory in 1978. The theory acknowledges the relevance of culture on the process of knowing (Kanselaar, 2002; McLeod, 2018). It believes that people are products of their social and cultural environment. According to Ellig \& Holmes (2011), Vygotsky believed that community plays an influential role in the importance of making meaning essentially, learning. The theory believes that a child's learning cannot be separated from the child's cultural background because culture determines how he or she relates with others, learn and think. This theory is relevant to this study because it acknowledges the relevance of culture in the teaching and learning processes by establishing a link between culture and the child's cognitive development.

This study, therefore, considered enhancing the pre-primary school children's cognitive competence (problem-solving, speaking, and listening skills) through culturally-based instructional strategy (indigenous songs, rhymes, games, stories, language of the immediate environment, and local materials) in Oyo State, Nigeria

\section{RESEARCH METHODS}

\section{Research question}

The research question was stated as follows to guide the study

Is there a difference before and after the treatment in children's cognitive competence in problemsolving, listening, and speaking?

\section{Hypothesis}

$\mathbf{H}_{\mathbf{0}} \mathbf{1}$ : There is no significant main effect of treatment on children's cognitive competence 


\section{Research Design}

The study used the pretest-posttest control group quasi-experimental research design to determine the impact of the treatment on pupils' cognitive competence. Pretest-posttest control group design is the type of quasi-experimental design in which the cognitive competence of the participants in the research is measured before and after the treatment in both the experimental and the control groups. This study observed how well the pre-primary school children exhibited the problem-solving, listening, and speaking skills of cognitive competence before as well as post-treatment. This was to ascertain that the groups were almost the same or significantly different in the exhibition of skills before treatment and to determine the extent to which the participants were knowledgeable about the content before and the shift in their knowledge after the experiment. In the end, that it may be justified that the post-competence of the preprimary school children is the result of the treatment, there must be a control group.

The research design is schematically represented thus:

$$
\begin{array}{lllll}
\mathrm{O}_{1} & \mathrm{X}_{1} & \mathrm{O}_{2} & -\mathrm{E} & \text { (Experimental Group) } \\
\mathrm{O}_{3} & \mathrm{X}_{2} & \mathrm{O}_{4} & -\mathrm{C} & \text { (Control Group) }
\end{array}
$$

Where $\mathrm{O}_{1}, 0_{3}$ represent pretest measures and $\mathrm{O}_{2}$ and $0_{4}$ represent posttest measures for experimental and control groups, respectively.

$\mathrm{X}_{1}$ represents culturally-based instructional strategy (Experimental group)

$\mathrm{X}_{2}$ represents conventional instructional strategy (Control Group)

\section{Research Participants}

Two local government areas (LGAs) (Ibadan North and Ibadan North-East) and two pre-primary schools (one public and one private) were purposively selected from each of the LGAs based on their willingness to participate in the study. An intact class of Nursery III children was selected per school and randomized into CIBS and conventional groups. A total of 74 pre-primary school children (44 males and 30 females) with a mean age of 5.61 participated in the study. There were 37 children in each of the groups.

\section{Data collection}

The study was carried out in three stages: the training of research assistants/administration of pretest, implementation of the treatment, and administration of posttest. The procedure lasted for ten weeks in the selected schools. The pre-primary school children in the experimental group were exposed to culturally-based instructional strategy (CBIS), which comprises methodology (indigenous songs, rhymes, games, and stories), medium of instruction (language of the immediate environment -Yoruba), and indigenous materials (such as beads of different colors, dry seeds, cowries to develop the skills. All these were used to expose children to hands-on activities that involve counting, grouping, sorting, and matching. Posters that contained Yorùbá numbers and alphabet with relevant pictures were made available to them to engage in making word-picture albums and word-formation. They also engaged in fixing puzzles, counting, grouping, sorting, and matching indigenous objects, and threading beads for problem-solving. Relevant indigenous stories, rhymes, and game songs were used to facilitate the acquisition of the skill of listening and speaking skills.

The pre-primary school children in the control group were exposed to the conventional instructional strategy (CIS). Researchers have established this strategy to be dominated by Western-oriented activities, such as foreign songs, rhymes, and games language. English was the medium of instruction adopted for the conventional group. Afterward, the posttest was administered to the two groups by the tenth week of 
the study. The instruments used were the Children's cognitive Competence Rating Scale $(r=0.89)$ and CIBS Instructional Guide. Compiled Relevant Indigenous Rhymes, Songs, and Games, Children's Indigenous Picture Storybook, Pictorial Charts on Indigenous Numbers and Alphabets.

\section{Data analysis}

Data were analysed using Paired sample t-test and Analysis of covariance. Paired t-test was used to show the difference between pretest and posttest scores of children. In contrast, Analysis of Covariance was used to control the effect of the extraneous variables in the study.

\section{FINDINGS AND DISCUSSION}

\section{Research Question:}

1. Is there a difference before and after the treatment in children's cognitive competence in problemsolving, listening, and speaking?

Table 1. Summary of paired t-test analysis showing the difference between pre and post scores of the children in cognitive competence

\begin{tabular}{|c|c|c|c|c|c|c|}
\hline Paired Variable & \multicolumn{2}{|c|}{ N Mean } & \multicolumn{2}{|c|}{ Std. E Mean Gain t } & \multicolumn{2}{|c|}{ df Sig. Remark } \\
\hline \multirow[t]{2}{*}{ Pre-problem solving } & 37 & 18.081 & 5.356 & & & \\
\hline & & & 11.946 & 9.321 & 36.000 & Significant \\
\hline Post-problem solving & 37 & 30.027 & 5.052 & & & \\
\hline \multirow[t]{2}{*}{ Pre-Listening } & 37 & 8.676 & 3.794 & & & \\
\hline & & & 14.946 & 13.047 & 36.000 & Significant \\
\hline Post Listening & 37 & 23.622 & 7.342 & & & \\
\hline \multirow[t]{2}{*}{ Pre-speaking } & 37 & 7.811 & 4.351 & & & \\
\hline & & & 17.000 & 15.039 & 36.000 & Significant \\
\hline Post-speaking & 37 & 24.811 & 5.671 & & & \\
\hline
\end{tabular}

Table 1 reveals that there was a difference between the mean scores of problem-solving skills at the pretest (18.08) and the posttest (30.03) of the thirty-seven (37) children in the experimental group that were exposed to the treatment. This difference was significant $(t=9.32 ; \mathrm{df}=36$;). The mean scores of listening skills at the pretest (8.68) differs from the posttest (23.62) of the children exposed to treatment. This difference was significant $(t=13.05 ; d f=36$;). The mean score of speaking skill at pretest (7.81) differs from the posttest (24.81) of the children exposed to treatment. It was significant $(\mathrm{t}=15.04 ; \mathrm{df}=$ 36 ;). 

Speaking and Listening: An Evidence in Oyo State Nigeria.

Oluyemisi Majebi, Esther Oduolowu

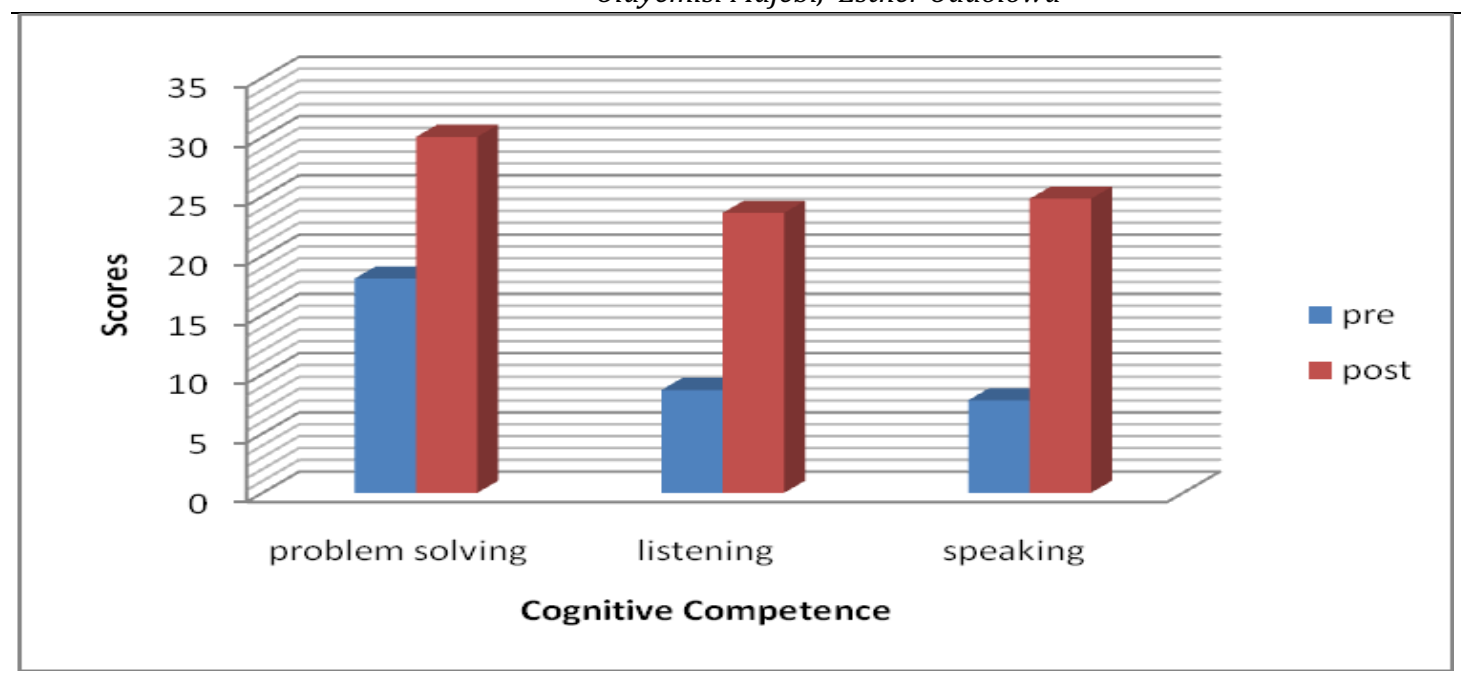

Fig. 2: Cognitive Competence before and after Treatment

\section{Hypothesis}

$\mathbf{H}_{\mathbf{0}} \mathbf{1}$ : There is no significant main effect of treatment on children's cognitive competence

Table 2: Summary of Analysis of Covariance (ANCOVA) on Cognitive Competence of Children Dependent Variable: post-conquest

\begin{tabular}{|c|c|c|c|c|c|c|}
\hline Source & Type III Sum & & & & & \\
\hline & f Squares & Df & Mean Square & $\mathbf{F}$ & ig. & tial \\
\hline & & & & & Eta & \\
\hline & & & & & Squ & \\
\hline Corrected Model & $9623.163^{a}$ & 8 & 1202.895 & 5.540 & .000 & .405 \\
\hline Intercept & 88205.041 & 1 & 88205.041 & 406.265 & .000 & .862 \\
\hline Precognitivecompetence & ce 49.830 & 1 & 49.830 & .230 & .633 & .004 \\
\hline Treatment & 2237.714 & 1 & 2237.714 & $* 10.307$ & .002 & .137 \\
\hline
\end{tabular}

* denotes significant difference at 0.05 level of significant

a. $\quad$ R Squared $=.405$ (Adjusted R Squared $=.332$ )

Table 2 indicates that there was a significant main effect of treatment on children's cognitive competence $\left(F(1,65)=10.31 ;\right.$ partial; $\left.\tilde{\eta}^{2}=0.14\right)$. Therefore, $\mathrm{H}_{0} 1$ was rejected. The effect size was $14 \%$.

Table 3 presents the magnitude of performance across the groups.

Table 3: Estimated Marginal Means on Cognitive Competence of Children 


\begin{tabular}{lccl}
\hline Variable & N & Mean & Std.E \\
\hline & & & \\
Pre score & 74 & 29.027 & - \\
Post Score & 74 & 77.597 & 2.622 \\
Treatment & & & \\
Control Group & 37 & 69.018 & 2.718 \\
Experimental Group & 37 & 86.177 & 4.544 \\
\hline
\end{tabular}

Table 3 shows the competent cognitive scores of the two groups of children. Out of a maximum mark of 99, the mean score of children in the control group was $69.02(69.72 \%)$, while that of the children in the experimental group was 86.18 (87.05\%). This implies that those exposed to CBIS exhibited significantly better cognitive competence in problem-solving, speaking, and listening skills than those exposed to conventional strategy.

\section{DISCUSSION}

Point 1: The study's finding reveals that there was a significant main effect of treatment (culturally-based Instructional Strategy) on pre-primary school children's cognitive competence (problem-solving, speaking, and listening skills). It simply means that the children exposed to CBIS gained more in the skills of cognitive competence than those exposed to conventional instructional strategy (CIS). This effectiveness corroborates the findings of different experimental studies that have been carried out on CBIS, such as Moyo (2009), Underwood (2009), Peterek (2009), Hills (2012), Mayfield (2012), Thoms (2014), Paulk, Martinez, and Lambeth (2014). These scholars confirmed that the strategy is effective in increasing student achievement in any subject area. It is also in line with the submission of Gay (2000) that all students will perform better on multiple measures of achievement when teaching is filtered through their own cultural experiences.

Point 2: The language of the medium of instruction - Yoruba adopted in this study as contrary to the conventional medium of instruction - English language at the pre-primary school level is also believed to have a significant effect on the acquisition of cognitive competence. The Six-Year Yoruba Medium Primary Project by Fafunwa, as reported by Agbedo, Abata-Ahura, Krisagbedo, and Edward (2012), demonstrated that a full six-year primary education in the mother tongue with the L2 taught as a subject was not only viable but gave better results than all-English schooling. Oribabor and Adeshina (2013) also confirmed that the use of the Yoruba language as a medium of instruction aided learning better than the foreign language.

Point 3: The indigenous materials used during the experiment also attracted children's attention and encouraged children's active involvement during the teaching and learning activities because some of them were new in the classroom. As identified by Yitbarek (2012), using indigenous materials makes teachers and learners aware of the resources to be found in their environment and stimulates creativity to use them. This could be one of the reasons why the Rivers Readers Project (nd) suggested that materials in the mother tongue of reasonable quality could be developed and utilized during the course of teaching and learning.

Point 4: The components of cognitive competence (problem-solving, listening, and speaking) selected for this study were also examined separately before and after the treatment. The results revealed that the pre-primary school children were exposed to the culturally-based instructional strategy with respect to the series of activities, such as the use of indigenous stories, rhymes, games-songs, materials, and language 
of the immediate environment exhibited higher skills of problem-solving, listening and speaking after the treatment. There was a difference between the mean scores of problem-solving skills before and after the children were exposed to treatment. This difference was significant. This might be because children were not limited to their conventional strategy of just providing answers to certain exercises; they were engaged with indigenous materials and various problem-solving activities such as counting, sorting, matching, grouping, fixing of puzzles, and word formation. This finding is in agreement with Deak (2000), who exposed pre-primary school children to a series of activities to develop problem-solving skills. The experiment yielded tremendous results: children were able to search for information to solve problems, and they could match familiar words. Mugweni, Mutereri, and Ganga (2012) assert that extensive involvement in traditional games and socio-dramatic play has been seen to improve children's memory and cognitive perspective-taking abilities.

Likewise, there was a difference between the mean score of listening skills before and after exposing the children to the treatment. Indigenous stories, songs, and rhyme were employed to facilitate this skill in pre-primary school children exposed to the treatment. This difference was shown to be significant. This finding also corroborates the finding of an experimental study carried out by Oduolowu and Akintemi (2014) that indigenous storytelling facilitated listening skills. Also, there was a difference between the mean score of the speaking skill before and after exposing the children to the treatment. This difference was significant. This means that indigenous stories, songs, rhymes, games, materials, and language of the immediate environment significantly affected the selected components of cognitive competence of the pre-primary school children after the treatment.

\section{CONCLUSION}

Based on the findings of this study, it can be concluded that culturally-based instructional strategy (CBIS) is better than the conventional instructional strategy that has dominated pre-primary school classrooms in Nigeria. The children exposed to CBIS gained more in the skills of cognitive competence than those exposed to conventional instructional strategy (CIS). They exhibited higher competence in problemsolving, listening, and speaking skills. Adopting CBIS exposes children to indigenous ways of learning that allow them to be actively involved in teaching and learning activities.

\section{Limitation and Further Research}

Getting the relevant indigenous songs, games, play, and materials relevant to the topic treated almost hindered the implementation of the experiment. Most of the indigenous ways of teaching are gradually going into extinction. Further studies on culturally-based instructional strategy should not be restricted to an aspect of the child's development (cognitive) but should be extended to cover the holistic development of children; none of the domains should be neglected or given more attention than the other. A longitudinal study should be adopted in implementing the strategy for greater achievement. A large number of pre-primary school children should be involved in this type of study.

\section{REFERENCE}

Agbedo C. U., Abata-Ahura L. I., Krisagbedo E. C. \& Edward C. (2012). Mother tongue and 
International Journal of Emerging Issues in Early Childhood Education (IJEIECE) Vol. 3 (2), 28-41 Correlational Study of Culturally-Based Instructional Strategy and Cognitive Competencies on Problem Solving, Speaking and Listening: An Evidence in Oyo State Nigeria.

Oluyemisi Majebi, Esther Oduolowu

pedagogic disability of the Nigerian school child: A case for revalorization of indigenous Nigerian languages A paper presented at the 4th congress on children with developmental and communication disorders @ Ebitimi Banigo Auditorium University of Port Harcourt, Port Harcourt Rivers State, Nigeria Retrieved from https://pdfs.semanticscholar.org/84de/cc2d707ec00a7a6d2114b5935461f19c0f01.pdf https://doi.org/10.7176/DCS

Akinwale A. R. (2013) Yoruba traditional education system: a veritable tool for salvaging the crisis laden education system in Nigeria Academic Journal of Interdisciplinary Studies Published by MCSER-CEMAS-Sapienza University of Rome Vol 2.6

$\begin{array}{lllll}\text { Retrieved } & \text { on } & 7^{\text {th }} & \text { Feb., } & 2014\end{array}$ https://www.mcser.org/journal/index.php/ajis/article/view/626/648.

DOI 10.5901/ajis.2013.v2n6p141

Alaska Native Knowledge Network (1998) Alaska Standards for culturally responsive schools Fairbanks: Alaska native knowledge network. University of Alaska Fairbanks. Retrieved from University of Alaska Fairbanks on 7th Feb., 2014

Azubuike 0. C. (2013) Consideration of culture in the development of home economics curriculum in Nigeria in International Interdisciplinary Conference On Education And Development Federal College Of Education (Technical), Umunze-Anambra State, Nigeria book of proceedings. Retrieved from www.mcser.org/journal /index.php/jesr/article/viewFile/2335/2310 on 6th March, 2015.

Berk L. E. and Winsler A. (2002) Scaffolding children's learning: Vygotsky and early childhood education. National Association for the Education of Young Children. Washington, DC USA.

Brown L. (2012) Developing effective listening skills in children. Retrieved from http://www.neverendingstories.co.za/educational-resources/items/2-developing effective listening-skillsinchildren.htm. on $26^{\text {th }}$ July, 2014.

Chartock, R. K. (2010) Strategies and lessons for culturally responsive teaching. A primer for K 12 teachers. USA: Pearson Education.

Coffery, H. (2008) Culturally responsive teaching. Learn NC Retrieved from http://www.learnnc.org/lp/pages/447425th Jan., 2015

Darling-Hammond L., Austin K., Lit I., Nasir N., Moll L., and Ladson Billings G. (2008) Session 6: The classroom mosaic: culture and learning. The learning classroom

Dawes, A. and Biersteker, L (2011) Early childhood development in handbook of African educational theories and practices. A generative teacher education curriculum Cameroon Human Development Resource Centre (HDRC). Nsamenang A. B. and Tchombe T.M.S. Eds. Retrieved on 9-6-2012 from http://www.thehdrc.org/ Handbook\%20of\% 20African\%20 Educational\%20 Theories\%20and\%20Practices. pdf

Deak, G. O. (2000) The growth of flexible problem solving preschool children: use changing verbal cues to infer multiple word meaning. Journal of Cognition and Development 1.2:157 19.1. Retrieved from https://ai2-s2-pdfs.s3.amazonaws.com/35f1/236e 3ce3e266ea435571b976ffd462b4a42e.pdf. 20th June. 2013

Durojaiye, S. M. (1977) Practical methods for nursery schools. Ibadan: Oxford University Press Nigeria.

Ekukinam, T. U. (2012) Production of instructional materials for early child care and education: the teachers' role in initiating entrepreneurial opportunities. Early child care and education for universities and colleges of education Q.I Obinaju. Ed. Uyo Soul Mate Press and Publishing Company Ltd

Erickson, F. (2010) Culture in society and in educational practices. J. A. Banks and C.A. McGee. 
International Journal of Emerging Issues in Early Childhood Education (IJEIECE) Vol. 3 (2), 28-41

Correlational Study of Culturally-Based Instructional Strategy and Cognitive Competencies on Problem Solving, Speaking and Listening: An Evidence in Oyo State Nigeria.

Oluyemisi Majebi, Esther Oduolowu

Eds. Multicultural education: Issues and perspectives $7^{\text {th }}$ ed. Hoboken: NJ: Wiley. 33-56.

Fakeye, D. O. (2010) Indigenous language education and the teaching and learning of English at primary schools. Nigeria Journal of Nigerian Languages and Culture 12. Enugu. Association for Promoting Nigerian Languages and Culture. 1:247- 255.

Fries-Gaither, J. (2009) Culturally responsive teaching: peoples of the Arctic. The Ohio State University. Retrieved from beyondpenguins.ehe.osu.edu > Peoples of the Arctic. On 25th Dec. 2014

Gay, G. (2000) Culturally responsive teaching; theory, research, and practice. New York: Teachers College Press.

Gwanfogbe, M. B. (2011) African's triple education heritage: A historical comparison in handbook of African educational theories and practices a generative teacher education curriculum Cameroon. Human Development Resource Centre (HDRC). A. B Nsamenang. and T.M.S Tchombe. Eds. Retrieved on $6^{\text {th }}$ June 2012 from http://www.thehdrc.org/Handbook\%20of\% 20African\%20 Educational\%20 Theories\%20and\%20Practices.pdf

Hill, A. L. (2012) Culturally responsive teaching: an investigation of effective practices for African American learners. A dissertation Retrieved on 6th June, 2013 from http://ecommons.luc.edu/luc_diss/353.

Jalongo, M. R. (2008) Learning to listen, listen to learn: building essential skills in young children Washington, DC: National Association for the Education of Young Children.

Kanselaar, G. (2002) Constructivism and socio-constructivism. Utrecht University Repository in NARCIS. 1 http://dspace.library.uu.nl/handle/1874/6684

Lubienski C. (2006) Charter, private, public schools and academic achievement: new evidence from NAEP mathematics data. National Center for the Study of Privatization in Education. Teachers' College, New York Columbia University.

Mayer, R. and Wittrock, M. (2009) Problem solving. The Gale Groups Retrieved from www.education. com/reference/article/problem-solving.

Mayfield, V. (2012) Culturally responsive practices in a school: closing an achievement gap: a case study. Dissertation Faculty of the Graduate School of the University of Colorado. Retrieved on 21th June, 2014 from eric.ed.gov/?id=ED542572.

Michelon, P. (2006) What are cognitive abilities and skills. National Association for School Psychology.Retrieved from http://sharpbrains.com/blog/2006/12/18/what-are-cognitiveabilities/on 21th June, 2014.

Moyo, D. T. (2009) Culturally responsive pedagogy in the early childhood classroom: an ethnography. ProQuest Dissertations and Theses Retrieved on 07-01-2013from http://ecommons.luc.edu/luc_diss/353.

McLeod, S. (2000) Lev Vygotsky's Sociocultural Theory. Retrieved from https://www.simplypsychology.org/simplypsychology.org-vygotsky.pdf on June 2, 2021

Mugweni, R. M., Mutereri, J. and Ganga, M. (2012) The impact of space on children's play: a case of four preschools in Masvingo city. International Journal of Academic Research in Progressive Education and Development 1.4:93-104 Retrieved from ir.msu.ac.zw:8080/xmlui/handle/11408/1380.

Obanya, P. A. I. (2007) African Education in the EFA Decade. Ibadan: Mosuro Publishers.

Obioha, U. P. (2010) Globalization and the future of African culture. Academic Journals Philosophical Papers and Reviews Retrieved on 9-6-2012http://www.academic journals.org/PPR. 2:1

Oduolowu, E. A. (1998) The relative effectiveness of open classroom and conventional strategies 
International Journal of Emerging Issues in Early Childhood Education (IJEIECE) Vol. 3 (2), 28-41

Correlational Study of Culturally-Based Instructional Strategy and Cognitive Competencies on Problem Solving, Speaking and Listening: An Evidence in Oyo State Nigeria.

Oluyemisi Majebi, Esther Oduolowu

on pupils's acquisition of the basic literacy and numeracy skills. Unpublished Ph.D. Thesis, Department of Teacher Education, University of Ibadan

Oduolowu, E. and Akintemi, E. A. (2014) Effect of storytelling on listening skills of primary one pupils in Ibadan North Local Government Area, Oyo State, Nigeria International Journal of Humanities and Social Science Vol. 4.9:100-107, USA Retrieved on 27th March, 2015 from www.ijhssnet.com/journals/Vol_4_No_9_July_2014/10.pdf.

Oduolowu, E. and Amosun, M. D. (2010) Developing listening skill in children for communication, interaction and learning, African Journal of Educational Research. Pub by Teacher Education Department, University of Ibadan. 14:1 and 2.

Okoro, 0. (2006) Philosophy of pre-primary education. Enugu: Ballins Publishers Nig. Limited.

Oribabor, A. O. and Adeshina, A. D. O. (2013) Mother tongue instruction and academic achievement of pupils in nursery schools. International Research Journal of Arts and Social Sciences. Retrieved from http://www.interesjournals.org/IRJASS. 2.5:131-133.

Paulk, S. M., Martnez, J. and Lambeth, D. T. (2014) Effects of culturally relevant teaching on seventh grade African American students.MLET: The Journal of Middle Level Education in Texas.Vol 1 Issue 1 Article 3. Retrieved on 7th Nov., 2015 from scholarworks.sfasu.edu/cgi/viewcontent.cgi?article=100.2andcontentmlet.

Peterek, E. (2009) Culturally responsive teaching in the context of mathematics: a grounded theory approach. Proquest dissertations and theses dissertation. Dissertation Graduate School of the University of Florida. Retrieved on June $18 \quad 2013$ from ufdcimages.uflib.ufl.edu/UF/E0/02/47/82/00001/peterek_e.pdf.

Ritterhouse, G. E. (2007) Perceptions of beginning teachers' preparation for culturally responsive teaching: voice from the field. Ph.D Dissertation. Department of Educational Leadership, Wichita State University. Retrieved from soar.wichita.edu/bitstream/handle/10057/1498/d07034.pdf?sequence=1

Rogoff ,B. (2003) The cultural nature of human development. Oxford: Oxford University Press.

Roy-Omoni, A. (2010) Nigeria culture and tradition: a call for decolonization. Journal of Nigeria Languages and Culture. 12.1.

Saifer S., Edwards, K., Ellis, D, Lena Ko, Stuczynski A., Dorfman, D. and Kirkham, J. (2005) Classroom to community and back using culturally responsive, standards-based teaching to strengthen family and community partnerships and increase student achievement. Northwest regional educational laboratory. Retrieved from oregonpirc.org/webfm_send/19.

Salami, I. A. (2014) Effects of activity-based strategies on primary school mathematics lesson plan and delivery skills among pre-service teachers in southwestern Nigeria. Unpublished Ph.D thesis, Dept. of Teacher Education, University of Ibadan.

Salami, I. A. and Oyaremi, M. K. (2012) Teachers' knowledge, use and perception of the relevance of Yorùbá indigenous child's play to preprimary and primary schools. Nigerian Education Research Journal 2.5. Retrieved from dspace.unza.zm:8080/ xmlui/bitstream/handle/123456789/.../Main\%20body.pdf?...3

Scrimsher, S. and Tudge, T. R. H. (2003) The teaching/learning relationship in the first years of school: some revolutionary implications of Vygotsky's theory. Retrieved from www.uncg.edu/hdf/facultystaff/Tudge/teachlearn.pdf.

Šolcová, P., (2011) Teaching Speaking Skills. Master's Diploma Thesis. Department of English and American Studies. Faculty of Arts. Masaryk University.

Thoms, J. (2014) The effects of culturally responsive pedagogy in a middle school avid class. An action research report. Retrieved from sophia.stkate.edu > SBPS > Education > MAE 
Thompson, J. (2010) What impact do culturally competent teachers have on the social inclusiveness of their students? Retrieved on 25-02-2013 from digital commons. usu.edu/cgi/viewcontent.cgi?article $=1566 \&$ context $=$ etd.

Tramel, A. (2011) The importance of developing listening skills and attention in children. Retrieved on Jan. 30, 2013 from http://www.livestrong.com/article/507882.

Underwood, P. H. (2009) Effects of culturally-responsive teaching practices on first grade students' reading comprehension and vocabulary gains. ProQuest Dissertations and Theses. Retrieved on 03-06-2013 from diginole.lib.fsu.edu/islandora/object/fsu\%3A253970.

UNESCO (2003). Education in a multilingual world (UNESCO Education Position Paper). Paris, France: United Nations Educational, Scientific and Cultural Organization. Retrieved on June 29, 2014 from http://unesdoc.unesco.org/images/0012/001297/129728e.pdf.

Vygotsky, L.S. (1978). Mind and society: The development of higher mental processes. Cambridge, MA: Harvard University Press.

Wang Q, Ceci S. J., Williams W. M., and Kopko, K. A. (2004) Culturally situated Cognitive competence. Retrieved from citeseerx.ist.psu.edu/viewdoc/download? doi=10.1.1.459 $.406 \&$ rep $=$ rep1.

Yitbarek S.( 2012) Low-cost apparatus from locally available materials for teaching-learning Science African Journal Chemical Education. (AJCE) special issue. Retrieved from www.ajol.info/index.php/ajce/article/download/82438/72591. 2.1: 32-47

Yussuf, M. A. and Adigun, J. T. (2010) The influence of school sex, location and types on students' academic performance. International Journal of Education and Science 2.2:81-85. Retrieved from krepublishers.com/...Journals/.../IJES-2-2-81-10-054-Yusuf-M-A-Tt.pdf https://doi.org/10.1080/09751122.2010.11889992 